\title{
Cytometric measurement of the DNA cell cycle in the presence of chlorophyll autofluorescence in marine eukaryotic phytoplankton by the blue-light excited dye YOYO-1
}

\author{
Frank J. Jochem ${ }^{1, *}$, Doris Meyerdierks ${ }^{2}$ \\ 'Institut für Meereskunde, Düsternbrooker Weg 20, D-24105 Kiel, Germany \\ ${ }^{2}$ Universität Bremen, FB II Meeresbotanik, Postfach 330440, D-28334 Bremen, Germany
}

\begin{abstract}
The novel blue-light excited fluorescent DNA dye YOYO- $1{ }^{\oplus}$ was tested on cultures of 8 eukaryotic phytoplankton species from the classes of Prymnesiophyceae, Bacillariophyceae, Coscinodiscophyceae, Prasinophyceae and Dinophyceae, and the coccoid cyanobacterium Synechococcus $\mathrm{sp}$. In all tested species, YOYO staining of formalin fixed cells allowed the differentiaton of cell cycle phases of G1, S, and $\mathrm{G} 2+\mathrm{M}$ in the presence of chlorophyll autofluorescence in flow cytometric analyses. Diel cell cycle patterns of Emiliania huxleyi and Skeletonema costatum grown under a light:dark cycle and under continuous light could be established. Under the light/dark cycle, DNA replication occurred during the night and cell division in the early morning in both species. However, $S$. costatum spent a longer fraction of their cell cycle in $S$ and $G 2+M$ phases than $E$. huxleyi did. Changes in cellular chlorophyll content and cell size could be observed in relation to cell cycle phasing. Cell division phasing was nearly lost under continuous light. Growth rates calculated from DNA cell cycle analyses agreed well with those established from cell counts.
\end{abstract}

KEY WORDS: Cell cycle $\cdot$ Cytometry $\cdot$ DNA $\cdot$ Growth rates

Phytoplankton population growth is the result of a balance between phytoplankton intrinsic growth (i.e. gross growth rates) and losses due to grazing, natural mortality and sedimentation. Phytoplankton intrinsic growth rates, thus, are essential in order to understand phytoplankton and food web dynamics as well as physiological and community responses to changing environmental conditions. In fact, a major criticism of a number of incubation experiments, e.g. those testing the iron hypothesis (Martin et al. 1989, 1990, de Baar et al. 1990), has been that they involve long-term bottle incubations which can only reveal community net

\footnotetext{
- Present address: The University of Texas at Austin, Marine Science Institute, 750 Channel View Drive, Port Aransas, Texas 78373,USA.E-mail: frank@emcs.de
}

growth as small grazers are often included within the bottles; moreover, growth in bottle incubations may be biased as larger grazers are overproportionally excluded from them, thereby altering the food web structure (Banse 1991).

DNA cell cycle analysis in combination with single cell analysis was introduced to overcome incubation biases as cellular DNA can be directly estimated from cells harvested from the studied system (Carpenter \& Chang 1988). DNA cell cycle analysis was tested both in phytoplankton cultures (Chang \& Carpenter 1988) and field studies (Chang \& Carpenter 1991), and appropriate algorithms allow for data analysis (McDuff \& Chisholm 1982, Vaulot 1992). Growth rates derived from DNA cell cycle analysis appear insensitive to the ambient grazing impact (Chang \& Dam 1993).

Flow cytometry distinguishes different sub-populations of phytoplankton by their specific combinations of size and pigment fluorescence. Preservation of chlorophyll autofluorescence is therefore essential to discriminate phytoplankton from other organisms and non-living particles. Common DNA dyes such as ethidium bromide and propidium iodide emit at wavelengths which interfere with the red chlorophyll fluorescence and require chlorophyll extraction prior to DNA staining (Olson \& Chisholm 1986, van Bleijswijk $\&$ Veldhuis 1995). Analysis of chlorophyll-extracted samples is, however, restricted to unialgal cultures (Brzezinski \& Conley 1994, Buma et al. 1995) or when one species of interest is largely dominant (van Bleijswijk \& Veldhuis 1995). The UV excitation required by DAPI and Hoechst 33342, whose blue fluorescence does not interfere with chlorophyll signals, is not available on most of the low-cost benchtop flow cytometers suitable for shipboard use. Successful cytometry application of these dyes is so far restricted to prokaryotic phytoplankton (Binder \& Chisholm 1990, 1995, Vaulot 
\& Partensky 1992, Vaulot et al. 1995, 1996) or eukaryotes after chlorophyll extraction (Boucher et al. 1991).

A new group of high fluorescence yield cyanine dyes has recently been introduced for DNA staining in electrophoretic gels (TOTO, TO-PRO, YOYO; Glazer \& Rye 1992). The blue-light excitable TOTO and TOPRO have been used for the cytometric quantification of marine bacteria ( $\mathrm{Li}$ et al. 1995) while YOYO- $1^{\text {(3) }}$ has been successfully used for DNA analysis in mammalian cells (Hirons et al. 1994) and bacteria (Marie et al. 1996). We present here a protocol for reliable and reproducible DNA cell cycle analysis in marine eukaryotic phytoplankton with YOYO- ${ }^{(*)}$, a modified dimer of the dye oxazole yellow (Hirons et al. 1994), in the presence of chlorophyll autofluorescence.

Material and methods. Cultures of Emiliania huxleyi (Reijksuniversiteit Groningen), Imantonia rotunda (CCMP 460), Isochrysis galbana (CCMP 463), Micromonas pusilla (CCMP 487) and Synechococcus strain $\mathrm{KB} 9001$ (isolated from Kiel Bight, Baltic Sea) were maintained at $18^{\circ} \mathrm{C}$ and $80 \mu \mathrm{E} \mathrm{m}^{-2} \mathrm{~s}^{-1}(14: 10 \mathrm{~h}$ light: dark cycle) in $\mathrm{f} / 20$ medium. The Antarctic Nitzschia lecointei (Universität Bremen) was cultured at $0^{\circ} \mathrm{C}$ under the same light and nutrient conditions. Skeletonema costatum (CCMP 1332) was grown under both continuous light $\left(75 \mu \mathrm{E} \mathrm{m}^{-2} \mathrm{~s}^{-1}\right)$ and $12: 12 \mathrm{~h}$ light:dark cycle $\left(150 \mu \mathrm{E} \mathrm{m}^{-2} \mathrm{~s}^{-1}\right)$ at $15^{\circ} \mathrm{C}$ in $\mathrm{f} / 2$ medium. Symbiodinium pulchrorum (APCX26, GJ Smith, UCLA) was cultured at $180 \mu \mathrm{E} \mathrm{m} \mathrm{m}^{-2} \mathrm{~s}^{-1}$ and $23^{\circ} \mathrm{C}$ in $\mathrm{f} / 2$ medium. Samples for DNA analysis were taken from batch cultures at mid to late logarithmic growth phase, fixed by formaldehyde ( $1 \%$ final concentration) and stored at $4^{\circ} \mathrm{C}$ in the dark (E. huxleyi, S. costatum, S. pulchrorum) or at $-20^{\circ} \mathrm{C}$ after shock-freezing in liquid nitrogen.

YOYO-1 ${ }^{\circledast}$ was provided by Molecular Probes (Eugene, OR) as $1 \mathrm{mM}$ stock solution in DMSO: $\mathrm{H}_{2} \mathrm{O}$ (dimethylsulfoxide, 1:4). For DNA staining, cells were spun down and washed in $0.5 \mathrm{ml}$ phosphate buffered saline (PBS). Cells were then incubated for $3 \mathrm{~h}$ at $37^{\circ} \mathrm{C}$ in $0.5 \mathrm{ml}$ PBS with $0.5 \mathrm{mg} \mathrm{m}^{-1}$ RNAse A (Sigma) and $0.05 \%$ Triton X-100 to degrade RNA which is also stained by YOYO. RNAse-treated cells were harvested by centrifugation, resuspended in $0.5 \mathrm{ml}$ PBS containing $400 \mathrm{nmol} \mathrm{l}^{-1}$ YOYO $0.5 \mathrm{mg} \mathrm{ml}^{-1}$ RNAse and $0.05 \%$ Triton X-100, and stained overnight at $4^{\circ} \mathrm{C}$ - this protocol provided the best results in DNA staining and cell cycle phase differentiation. Treatment with low concentration Triton X-100 was found necessary for sufficient cell membrane permeabilization to let the DNA dye and RNAse enter the cells freely. Triton concentration was kept to a minimum though to prevent cell rupture due to the aggressive detergent. Cells were transferred to PBS prior to cytometric analysis to reduce background fluorescence by the dye
Sample analyses were performed on a BD FACSort flow cytometer equipped with a $488 \mathrm{~nm} 15 \mathrm{~mW}$ laser at a flow rate of $0.2 \mu l \mathrm{~s}^{-1} .10000$ cells were processed for each measurement. Chlorophyll fluorescence was collected through a $650 \mathrm{~nm}$ long pass filter, and the green YOYO-DNA-complex fluorescence through a 530/ $30 \mathrm{~nm}$ band pass filter. Signals for Forward Angle Light Scatter (FSC), Side Angle Light Scatter (SSC) and chlorophyll fluorescence were recorded on 4 decades log scales, and those for YOYO-DNA fluorescence on a 1024 channels linear scale. Data acquisition and analysis for FSC, SSC and chlorophyll fluorescence were performed by BD Lysys II software. DNA signals were processed from the Lysys II listmode files by BD CellFit software using the SOBR (Sum of Broadened Rectangles) model (Dean 1987).

Chains of Skeletonema costatum were broken down to single cells by vortexing prior to cytometric analysis and only the singles were recorded for DNA analysis. Since not all chain fragments broke into single cells, cell numbers were estimated by counting ten $1 \mathrm{~mm}^{2}$ fields in a Neubauer chamber. Short $(<1 \mathrm{~min})$ vortexing produced, however, enough singles to measure 5000 cells within less than 2 min on the flow cytometer, and longer vortex treatment did not improve the fraction of singles. Cell breakage as derived from the accumulation of debris in cytometric analyses was low after 1 min but increased with longer vortexing.

Results and discussion. YOYO staining gave reasonably good results in cytometric DNA analysis in all tested marine algae and cyanobacteria (Fig. 1). DNA histogram analysis allowed differentiation of dividing and non-dividing cells and calculation of G1 (non-replicating cells), S (cells in the process of DNA replication), and $\mathrm{G} 2+\mathrm{M}$ (cells containing the double amount of DNA + cells undergoing mitosis) phase fractions by the Cellfit software. Both the coefficient of variation (CV) of the G1 peak, which represents the broadness of the frequency distribution of G1-cells in cytometric DNA measurements (Fig. 1), and the ratio of the $G 2$ peak fluorescence to the G1 peak fluorescence (G2/G1) are commonly accepted as quality controls of DNA histograms (Shankey et al. 1993). CVs and G2/G1 ratios for histograms depicted in Fig. 1 are given in Table 1.

CVs ranged from 6 to $15 \%$. Emiliania huxleyi, Isochrysis galbana, Nitzschia lecointei, and Synechococcus sp. gave the best CVs of less than $8.0 \%$ in the presented experiments and below $10 \%$ over all analyses performed (data not presented). G2/G1 ratios for the flagellates and Synechococcus were close to the theoretical value of 2.0 (1.93 to 2.03 over all analyses) whereas those of the diatoms generally ranged from 1.83 to 1.92 . Applying YOYO with a slightly different staining protocol to heterotrophic bacteria and the marine phototrophic prokaryote Prochlorococcus mar- 
Table 1. DNA cell cycle analysis of different phytoplankton species, quality data of histograms depicted in Fig. 1

\begin{tabular}{|llrc|}
\hline Species & Class & CV $(\%)$ & G2/G1 \\
\hline Eniliania huxleyi & Prymnesiophyceae & 6.8 & 1.93 \\
Isochrysis galbana & Prymnesiophyceae & 11.8 & 1.93 \\
Imantonia rotunda & Prymnesiophyceae & 7.5 & 1.97 \\
Nitzschia lecointei & Bacillariophyceae & 7.8 & 1.87 \\
Thalassiosira weissfloggii & Coscinodiscophyceae & 12.7 & 1.71 \\
Skeletonema costatum & Coscinodiscophyceae & 12.8 & 1.91 \\
Micromonas pusilla & Prasinophyceae & 13.6 & 2.00 \\
Symbiodinium pulchrorum & Dinophyceae & 9.2 & 2.00 \\
Synechococcus sp. & Cyanophyceae & 7.0 & 1.97 \\
\hline
\end{tabular}

0.8 to $2.4 \%$. Precision and accuracy for S and G2 phase estimates ranged below $17 \%$, varying among species, except $\mathrm{S}$ phase precision in $N$. lecointei. The lower $\mathrm{G} 2 / \mathrm{G} 1$ ratio, i.e. the smaller distance between G1 and G2 peaks in DNA histograms, might have caused the exceptionally low precision in the latter by exposing the analysis software to $\mathrm{S}$ phase modeling problems. Again, none of the hitherto published DNA analyses give precision or accuracy estimates; only Vaulot \& Partensky (1992) report a G1 precision of $8 \%$ in their DAPI staining of Prochloracoccus marinus without giving an accuracy estimate.

inus, Marie et al. (1996) report CVs of 2.9 to $12.9 \%$ and $\mathrm{G} 2 / \mathrm{G} 1$ ratios of 1.88 to 2.01 . Their protocol involved an order of magnitude less dye concentration and shorter incubations; applied to the eukaryotic algae tested here it failed to show cell cycle phase separation.

Among the other new blue-excitable and green emitting dyes, similar results were obtained for SYBR Green staining in cultures of Synechococcus sp., Prochlorococcus marinus (CV 8 to $10 \%$ ), and marine eukaryotic picoalgae (CV 10 to $13 \%$; Marie et al. 1997). A thorough study of the DNA content in eukaryotic algae by Veldhuis et al. (1997) resulted in CVs of 7.1 to $53 \%$ (mean $17.5 \pm 8.5 \%$ ) for PicoGreen and 4.6 to $43 \%$ (mean $17.4 \pm 7.0 \%$ ) for SYTOX Green. The authors' protocol (only $0.2 \mu \mathrm{g} \mathrm{ml}^{-1}$ RNAse for $1 \mathrm{~h}$ at room temperature) might, however, have resulted in incomplete RNA degradation obscuring their DNA signals. None of the other published work on cytometric DNA analysis in eukaryotic phytoplankton (Brzezinski et al. 1990, Brzezinski \& Conley 1994, van Bleijswijk \& Veldhuis 1995) or the marine prokaryotic phototrophs P. marinus and Synechococcus sp. (Binder \& Chisholm 1990, 1995, Vaulot \& Partensky 1992) gave quality measures for their data. But from their experiments, Veldhuis et al. (1997) refer to 'much higher CVs' for propidium iodide and Hoechst dye as compared to their PicoGreen and SYTOX data.

Analyses on Emiliania huxleyi, Imantonia rotunda, Skeletonema costatum, Nitzschia lecointei and Symbiodinium pulchrorum were used to estimate precision (variance among replicate measurements of the same preparation) and accuracy (variance among replicate preparations of the same samples with 5 to 8 replicate measurements for each single preparation). Variances were generally higher for $S$ and $G 2+M$ than for $G 1$ phase estimates (Table 2). Precision for G1 was 0.6 to $3.1 \%$, and accuracy

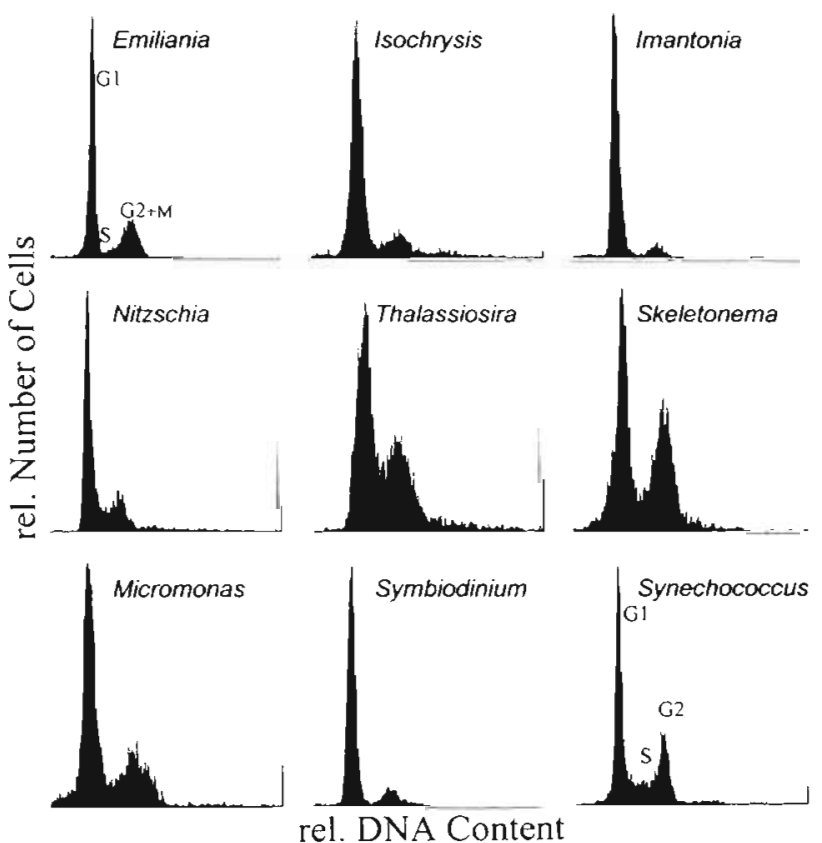

Fig. 1. Histograms of cellular DNA of 9 phytoplankton species stained with YOYO. Samples were taken at mid- to end-log phase of the cultures and different heights of $\mathrm{G} 2+\mathrm{M}$ peaks reflect different growth rates among cultures. (Note that for Synechococcus sp. the second peak is assigned 'G2' since prokaryotes do not exhibit a mitosis [M] phase)

Table 2. Precision (replicate cytometric analysis) and accuracy (replicate preparations) estimates for DNA cell cycle analysis in different phytoplankton species (coefficients of variances [\%], SD/Mean $\times 100, \mathrm{n}=$ number of analyses; $\mathrm{N}=$ number of preparations $\times$ number of analyses per preparation)

\begin{tabular}{|lrrrrrrrrr|}
\hline Species & \multicolumn{4}{c}{ Precision } & \multicolumn{4}{c|}{ Accuracy } \\
& G1 & S & G2+M & n & G1 & S & G2+M & N \\
\hline Emiliania huxleyi & 1.56 & 12.39 & 6.54 & 7 & 2.07 & 14.99 & 6.62 & $5 \times 5$ \\
Imantonia rotunda & 1.19 & 13.57 & 13.37 & 4 & 2.42 & 1.82 & 12.03 & $4 \times 5$ \\
Skeletonema costatum & 2.40 & 6.90 & 6.69 & 5 & & & & \\
Nitzschia lecointei & 3.07 & 54.61 & 3.44 & 6 & 0.79 & 16.24 & 12.31 & $2 \times 5$ \\
Symbiodinium pulchrorum & 0.63 & 6.30 & 5.50 & 8 & 2.20 & 5.43 & 13.68 & $6 \times 8$ \\
\hline
\end{tabular}




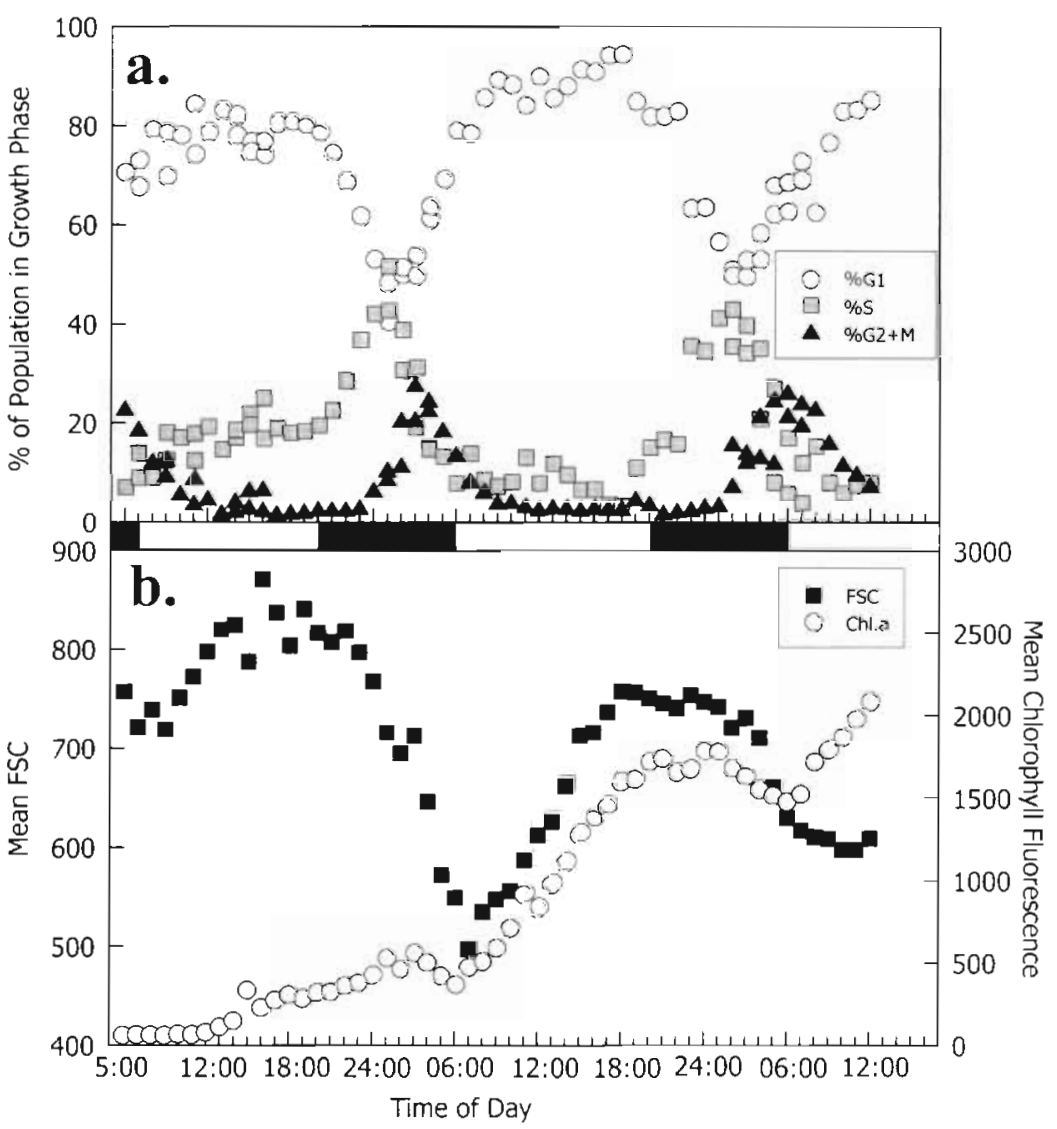

Fig. 2. Emiliania huxleyi. (a) Diel changes of cell cycle fractions under light/dark growth (b) diel changes in cellular chlorophyll (mean chlorophyll fluorescence) and cell size (mean FSC) erdierks 1997). Concomitant with cell division and cell size patterns, cellular chlorophyll exhibited a daily minimum in the early morning (Fig. 2b) which also remained obvious after normalizing cellular chlorophyll for FSC changes (data not shown). The same diel division pattern could be established for Imantonia rotunda, Isochrysis galbana, and Nitzschia lecointei; only Synechococcus sp. seems to lack strong cell division phasing (data not depicted).

A diel division pattern also occurred in Skeletonema costatum grown under a 12:12 h light:dark cycle but is nearly lost under continuous light (Fig. 3). The continuous light incubation should reveal to what extent the diel cell cycle pattern is intrinsically or light-driven. Presented data were obtained after 1 wk adaptation to continuous light which proved sufficient to loose most of the cell division phasing in this species.

For clarity of Fig. 3, only the G1 fraction is plotted as data points for both cultures; fractions of $S$ and $G 2+M$ for the light/dark culture are included as dotted lines from modeling their single data points by a periodic sine/cosine function (Chang \& Carpenter 1990) of:
Under 14:10 h light:dark cycle conditions sampled over $55 \mathrm{~h}$, DNA replication (S phase) in Emiliania huxleyi commenced during the dark phase and cells underwent cell division (passing from $\mathrm{G} 2+\mathrm{M}$ to $\mathrm{G} 1$ phase) upon illumination (Fig. 2a). Cell division could also be clearly seen in a sharp decrease in mean FSC as a measure of cell size (Fig. 2b). Over the light period, cells more or less regained their original cell size. Chlorophyll fluorescence, measured as red fluorescence $>610 \mathrm{~nm}$ or $>650 \mathrm{~nm}$, depending on the individual instrument setup, has proven to be linearly related to cellular chlorophyll concentrations in laser-based flow cytometers (Li et al. 1993, Graziano et al. 1996, Veldhuis \& Kraay in press). Cellular chlorophyll generally increased during the culture's growth as has been established from parallel culture experiments under similar growth conditions as well (Mey-

$$
f(t)=a_{0}+a_{1} \cos \left(\frac{2 \pi}{24} t\right)+b_{1} \sin \left(\frac{2 \pi}{24} t\right)+a_{2} \cos \left(\frac{2 \pi}{12} t\right)+b_{2} \sin \left(\frac{2 \pi}{12} t\right)
$$

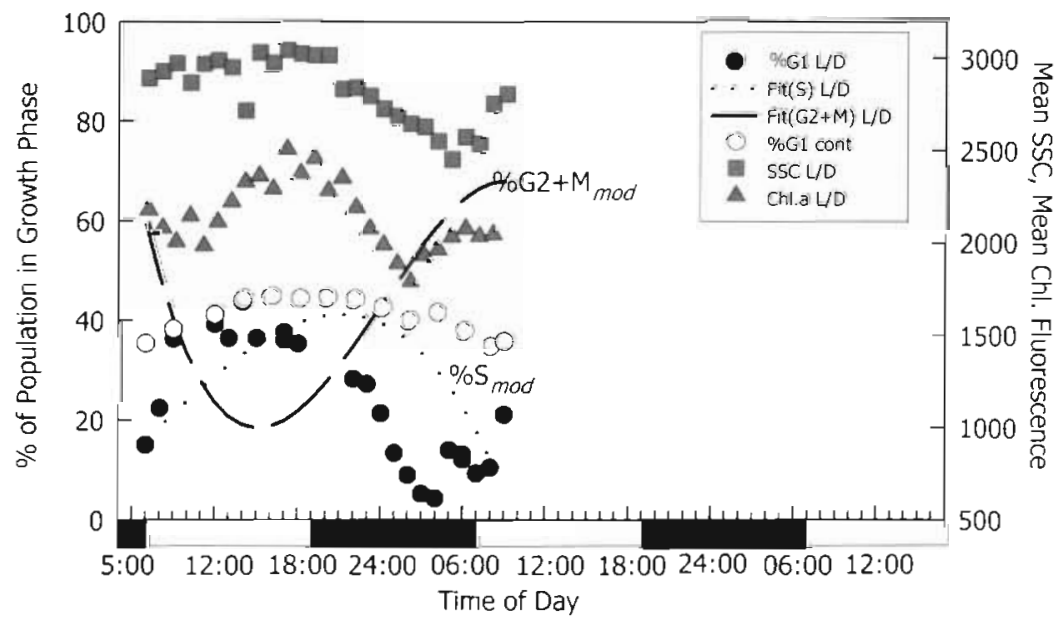

Fig. 3. Skeletonema costatum. Diel changes of cell cycle fractions $(\% \mathrm{G} 1$ as solid circles, \%S and \% $\mathrm{G} 2+\mathrm{M}$ indicated by lines from fitting the data points to a sine/cosine period function, see text) and cellular chlorophyll (mean chlorophyll fluorescence) and cell size (mean SSC) under light/dark (L/D) growth. Open circles present \%G1 under continuous light (CL) growth 
in which $a_{0}, a_{1}, a_{2}, b_{1}$, and $b_{2}$ are the regression coefficients of the respective function fit to time $(t)$. Fractions of $\mathrm{S}$ and $\mathrm{G} 2+\mathrm{M}$ phases under continuous light amounted to $17.9 \pm 3.8 \%$ and $42.0 \pm 3.3 \%$, respectively. Taking SSC with better resolution than FSC as a relative measure for cell size, light/dark Skeletonema costatum also exhibited a decrease in cell size in the early morning, indicating cell division has occurred. Cellular chlorophyll was highest at the end of the light period but had its minimum earlier than cell size (Fig. 3). Cellular chlorophyll concentrations oscillated between $0.33 \mathrm{pg} \mathrm{cell}^{-1}$ in the morning and $0.43 \mathrm{pg}$ cell $^{-1}$ during night (Y. Gao pers. comm.) - presenting a $30 \%$ increase over the light period. Both cell size and cellular chlorophyll remained constant under continuous light (data not shown).

Cell division phasing under a constant light/dark cycle makes perfect sense for a highly proliferating population: after photosynthesis during the day, energy resources are used during the night for DNA replication and cell division metabolism. By division in the early morning, daughter cells are prepared for another day of photosynthesis at the onset of light. It can be assumed that marine phytoplankton in ecosystems exhibiting a relatively constant light/dark cycle shows a similar cell division phasing. In fact, similar division patterns have been revealed by DNA analysis in marine dinoflagellates in Long Island Sound and Caribbean waters (Chang \& Carpenter 1991, 1994) and in Emiliania huxleyi in Norwegian coastal waters (van Bleijswijk \& Veldhuis 1995).

Although both Skeletonema costatum and Emiliania huxleyi displayed generally the same diel division pattern, detailed analysis reveals a distinct difference in cell cycle phasing between both species: whereas the time course of cell cycle phase fractions of $S$. costatum could be very tightly modeled by a sine/cosine periodic function (Eq. 1), those of E. huxleyi could not. Comparison of Figs. 2a \& 3 shows that cell cycle phasing in $S$. costatum is a more harmonic function of time whereas $E$. huxleyi passed through $\mathrm{S}$ and $\mathrm{G} 2+\mathrm{M}$ phases much faster (duration of $\mathrm{G} 2+\mathrm{M}$ phase as taken from Figs. 2a $\& 3: 8 \mathrm{~h}$ for $S$. costatum, $5 \mathrm{~h}$ for $E$. huxleyi). It has been documented that some diatoms spend relatively long fractions of their generation time in $\mathrm{G} 2+\mathrm{M}$ phase (up to $35-42 \%$ equivalent to $2-8 \mathrm{~h}$; Brzezinski et al. 1990). Based on generation times of about $24 \mathrm{~h}, S$. costatum and E. huxleyi spent $21 \%$ and $33 \%$ of their generation times in $\mathrm{G} 2+\mathrm{M}$ phase. The longer residence time in $\mathrm{G} 2+\mathrm{M}$ phase in diatoms may be attributed to the necessity of silica vesicle deposition after mitosis but before cell division.

To estimate growth rate via cell cycle analysis, 2 pieces of information are required: the fraction of proliferating cells $\left(f_{x}\right)$ which are involved in a terminal event' of the cell cycle, i.e. in S or G2+M phase, and the transition time $\left(T_{D}\right)$ for a cell to complete the terminal event (McDuff \& Chisholm 1982). A well-defined procedure to estimate growth rates from DNA staining which is based on a functional model of the cell cycle (Carpenter \& Chang 1988) has been applied:

$$
\mu=\frac{1}{n T_{D}} \sum_{i=1}^{n} \ln \left(1+f_{\mathrm{S}}\left[t_{i}\right]+f_{\mathrm{G} 2+\mathrm{M}}\left[t_{i}\right]\right)
$$

where $T_{D}$ is the time difference between the maximum of $\mathrm{S}$ and $\mathrm{G} 2+\mathrm{M}$ phases, $n$ is the number of samples/ measurements, and $f_{\mathrm{S}}\left(t_{1}\right)$ and $f_{\mathrm{G} 2+\mathrm{M}}\left(t_{i}\right)$ are the fractions of $\mathrm{S}$ and $\mathrm{G} 2+\mathrm{M}$ phases at each timepoint $t_{1}$. Mean daily growth rates estimated from DNA cell cycle analyses are compared to estimates from cell number increases in Table 3. Growth rates for Skeletonema costatum from DNA analyses and cell counts agree well. For Emiliania huxleyi, no cell numbers are available for the DNA experiment but the growth rate of $0.78 \mathrm{~d}^{-1}$ is close to $0.72 \mathrm{~d}^{-1}$ obtained from parallel growth experiments at similar culture conditions (Meyerdierks 1997), and the difference $(7.7 \%)$ is well below the reported error of the used method (Eq. 2) to derive DNA growth rates (Chang \& Carpenter 1990).

Table 3. Comparison of daily growth rates based on DNA cell cycle analysis ( $\mu \mathrm{DNA}$ ) and cell counts ( $\mu$ Count) in different light/dark and continuous light culture experiments of Skeletonema costatum

\begin{tabular}{|lcc|}
\hline Expt & $\mu$ DNA & $\mu$ Count \\
\hline Light/dark 1 & 0.54 & 0.55 \\
Light/dark 2 & 0.55 & 0.64 \\
Cont. light 1 & 0.50 & 0.49 \\
Cont. light 2 & 0.51 & 0.45 \\
\hline
\end{tabular}

Both precision and accuracy of around $2 \%$ for G1 phase estimates makes the presented protocol a useful tool for cell cycle analysis and growth rate estimates, which allowed us to establish the diel division patterns shown for Emiliania huxleyi and Skeletonema costatum. Growth rate estimates from diel DNA cycles corresponded closely to those from cell counts. Among available DNA cell cycle analyses in marine eukaryotic algae, the present protocol presents an improvement in terms of quality measures. In some species, CVs even satisfied quality standards for clinical flow cytometry of $<8 \%$ (Shankey et al. 1993). Due to its intercalating binding to double-stranded DNA, YOYO's fluorescence yield is proportional to the total DNA content of cells and independent of the base-pair composition (Glazer \& Rye 1992, Rye et al. 1992) and should, therefore, present a universal DNA probe for a variety of species. 
Preserving the chlorophyll fluorescence signal is a prerequisite for field applications and reasonable results for delicate species such as Emiliania huxleyi and other phytoflagellates reveal that involved centrifugation also does not prevent their analysis. In fact, it proved that proper fixation procedures, especially freezing versus non-freezing in liquid nitrogen depending on each species, had a higher impact on cell preservation and analysis quality than the subsequent staining protocol. In their study of PicoGreen and SYTOX Green, Veldhuis et al. (1997) report a significant drop in fluorescence yield by $50 \% 120$ min after their 15 to 30 min staining period and warrant a careful timing of measurements. In contrast, YOYO resulted in a stable DNA-dye-complex $;$ if stored cool and dark, fluorescence yield and histogram qualities were unchanged even after a couple of days - which is most appropriate for the preparation and analysis of large sample sets.

Acknowledgements. We thank C. Dormann, T. Mokros and Y Gao for their assistance in sampling the diel studies. This work was funded by DFG Jo 192/5

\section{LITERATURE CITED}

Banse K (1991) Rates of phytoplankton cell division in the field and iron enrichment experiments. Limnol Oceanogr $36: 1886-1898$

Binder BJ, Chisholm SW (1990) Relationship between DNA cycle and growth rate in Synechococcus sp. strain PCC 6301. J Bacteriol 172:2313-2319

Binder BJ, Chisholm SW (1995) Cell cycle regulation in marine Synechococcus sp. strains. Appl Environ Microbiol 61:708-717

Boucher N, Vaulot D, Partensky F (1991) Flow cytometric determination of phytoplankton DNA in cultures and oceanic populations. Mar Ecol Prog Ser 71:75-84

Brzezinski MA, Conley DJ (1994) Silicon deposition during the cell cycle of Thalassiosira weissfloggii (Bacillariophyceae) determined using dual rhodamine-123 and propidium iodide staining. J Phycol 30:45-55

Brzezinski MA, Olson RJ, Chisholm SW (1990) Silicon availability and cell-cycle progression in marine diatoms. Mar Ecol Prog Ser 67:83-96

Buma AGJ, van Hanna EJ, Roza L, Veldhuis MJW, Gieskes WWC (1995) Monitoring ultraviolet-B-induced DNA damage in individual diatom cells by immunofluorescent thymine dimer detection. J Phycol 31:314-321

Carpenter EJ, Chang J (1988) Species-specific phytoplankton growth rates via diel DNA synthesis cycles. I. Concept of the method. Mar Ecol Prog Ser 43:105-111

Chang J, Carpenter EJ (1988) Species-specific phytoplankton growth rates via diel DNA synthesis cycles. II. DNA quantification and model verification in the dinoflagellate Heterocapsa triquetra. Mar Ecol Prog Ser 44:287-296

Chang J, Carpenter EJ (1990) Species-specific phytoplankton growth rates via diel DNA synthesis cycles. IV. Evaluation of the magnitude of error with computer-simulated cell populations. Mar Ecol Prog Ser 65:293-304

Chang J, Carpenter EJ (1991) Species-specific phytoplankton growth rates via diel DNA synthesis cycles. V. Application to natural populations in Long Island Sound. Mar Ecol Prog Ser 78:115-122

Chang J, Carpenter EJ (1994) Active growth of the oceanic dinoflagellate Ceratium teres in the Caribbean and Sargasso Seas estimated by cell cycle analysis. J Phycol 30: $375-381$

Chang J, Dam HG (1993) The influence of grazing on the estimation of phytoplankton growth rate via cell cycle analysis: modeling and experimental evidence. Limnol Oceanogr 38:202-212

Dean PN (1987) Data analysis in cell kinetics research. In: Gray JW, Darzynkiewicz Z (eds) Techniques in cell cycle analysis, Chapter 8 . Humana Press, Clifton, NY, p 207-253

de Baar HJW, Buma AGJ, Nolting RF (1990) On iron limitation of the Southern Ocean: experimental observations in the Weddell and Scotia Seas. Mar Ecol Prog Ser 65: $105-122$

Glazer AN, Rye HS (1992) Stable dye-DNA intercalation complexes as reagents for high-sensitivity fluorescence detection. Nature 359:859-861

Graziano LM, Geider RJ, Li WKW, Olaizola M (1996) Nitrogen limitation of North Atlantic phytoplankton: analysis of physiological condition in nutrient enrichment experiments. Aquat Microb Ecol 11:53-64

Hirons GT, Fawcett JJ, Crissman HA (1994) TOTO and YOYO: new very bright fluorochromes for DNA content analysis by flow cytometry. Cytometry 15:129-140

Li WKW, Zohary T, Yacobi YZ, Wood AM (1993) Ultraphytoplankton in the eastern Mediterranean Sea: towards deriving phytoplankton biomass from flow cytometric measurements of abundance, fluorescence and light scatter. Mar Ecol Prog Ser 102:79-87

Li WKW, Jellett JF, Dickie PM (1995) DNA distributions in planktonic bacteria stained with TOTO or TO-PRO. Limnol Oceanogr 40:1485-1495

Marie D, Vaulot D, Partensky F (1996) Application of the novel nucleic-acid stains YOYO-1, YO-PRO-1 and PicoGreen for flow cytometric analysis of marine prokaryotes. Appl Environ Microbiol 62:1649-1655

Marie D, Patensky F, Jacquet S, Vaulot D (1997) Enumeration and cell cycle analysis of natural populations of marine picoplankton by flow cytometry using the nucleic acid stain SYBR Green I. Appl Environ Microbiol 63:186-193

Martin JH, Gordon RM, Fitzwater SE, Broenkow WW (1989) VERTEX: phytoplankton/iron studies in the Gulf of Alaska. Deep-Sea Res 36:649-680

Martin JH, Fitzwater SE, Gordon RM (1990) Iron deficiency limits phytoplankton growth in Antarctic waters. Global Biogeochem Cycles 4:5-12

McDuff RE, Chisholm SW (1982) The calculation of in situ growth rates of phytoplankton populations from fractions of cells undergoing mitosis: a clarification. Limnol Oceanogr $27: 783-788$

Meyerdierks D (1997) Zur Ökophysiologie des Dimethylsulfoniumpropionat (DMSP)-Gehaltes temperierter und polarer Phytoplanktongemeinschaften im Vergleich mit Laborkulturen der Coccolithophoride Emiliania huxleyi und der antarktischen Diatomee Nitzschia lecointei. Ber Polarforsch 233:1-198

Olson RJ, Chisholm SW (1986) Effects of light and nitrogen limitation on the cell cycle of the dinoflagellate Amphidinium carteri. J Plankton Res 8:785-793

Rye $\mathrm{H}$, Yue S, Wemmer D, Quesada M, Haugland R, Mathies R, Glazer A (1992) Stable fluorescent complex of doublestranded DNA with bis-intercalating asymmetric cyanine dyes: properties and applications. Nucleic Acids Res 20: $2803-2812$ 
Shankey TV, Rabinovitch PS, Bagwell B, Bauer KD, Duque RE, Hedley DW, Mayall BH, Wheeless L (1993) Guidelines for implementation of clinical DNA cytometry. Cytometry $14: 472-477$

Van Bleijswijk JDL, Veldhuis MJW (1995) In situ gross growth rates of Emiliania huxleyi in enclosures with different phosphate loading revealed by diel changes in DNA content. Mar Ecol Prog Ser 121:271-277

Vaulot D (1992) Estimate of phytoplankton division rates by the mitotic index method: the $\mathrm{f}_{\max }$ approach revisited. Limnol Oceanogr 37:644-649

Vaulot D, Partensky F (1992) Cell cycle distribution of prochlorophytes in the north western Mediterranean Sea. Deep-Sea Res 39:727-742

Editorial responsibility: Otto Kinne (Editor),

Oldendorf/Luhe, Germany
Vaulot D, Marie D, Olson RJ, Chisholm SW (1995) Growth of Prochlorococcus, a photosynthetic prokaryote in the equatorial Pacific Ocean. Science 268:1480-1482

Vaulot D, LeBot N, Marie D, Fukai E (1996) Effect of phosphorus on the Synechococcus cell cycle in surface Mediterranean waters during summer. Appl Environ Microbiol 62:2527-2533

Veldhuis MJW, Kraay GW (in press) Application of flow cytometry in marine phytoplankton research: current applications and future perspectives. Sci MarVeldhuis MJW, Cucci TL, Sieracki ME (1997) Cellular DNA content of marine phytoplankton using two new fluorochromes taxonomic and ecological implications. J Phycol 33 $527-541$

Submitted: January 26, 1999; Accepted: May 12, 1999 Proofs received from author(s): August 9, 1999 